\title{
Indian Freedom and Indian Slavery in the Portuguese Amazon (1640-1755) ${ }^{1}$
}

\author{
Rafael Chambouleyron
}

\section{Introduction}

Compared to other regions of America, the Amazon basin-situated on the northwest of the Portuguese possessions-was conquered and occupied in a later period of the Portuguese colonization of the continent. It was only during the 1610s, that the crown undertook the occupation of that region in a systematic and definitive way. During the early 1620 , when the Spanish and the Portuguese monarchies were united, ${ }^{2}$ the crown founded an independent province in the north, the Estado do Maranhão-the State of Maranhão, formed by two main captaincies, Pará (or Grão-Pará) and Maranhão. This decision was based upon the distance between Maranhão and the capital of Brazil, in Bahia, and the difficulties of traveling along the north coast, owing to contrary winds and currents. Not only was the state of Maranhão a separate province of the Portuguese dominions in South America, but its colonization also followed different paths compared to the other "conquests" of Portugal on the continent. In fact, the Amazon region was characterized by several distinct features: its frontier status (bordering Spanish, French, and Dutch possessions), by the dispersion of its population over a vast territory, by the importance of forest products in its economy and thereby the significance of its sertão (the hinterland), and by the crucial role played by Indian laborers.

During the seventeenth century, the settlers and the royal and local authorities soon discovered the importance of the region's native population and

1 This research was sponsored by the Conselho Nacional de Desenvolvimento Científico e Tecnológico $(\mathrm{CNPq})$ and the Fundação de Amparo à Pesquisa do Estado do Pará (FAPESPA). I would like to thank Dr. Márcia Mello and Dr. Karl-Heinz Arenz for their comments and suggestions.

2 From 1580 until 1640 , owing to dynastic reasons, the Portuguese crown belonged to the kings of Castile. For a recent analysis on the consequences of this period for the region, see: Guida Marques, "Entre deux empires: le Maranhão dans l'Union ibérique (1614-1641)," Nuevo Mundo, Mundos Nuevos, 2010, http://nuevomundo.revues.org/59333, accessed on Jan. 16, 2012; Alírio Cardoso, "A conquista do Maranhão e as disputas atlânticas na geopolítica da União Ibérica (1596-1626)," Revista Brasileira de História vol. 31, no. 61 (2011): 317-338. 
widely used Indian workers. Natives were the main laborers in transportation by rowing canoes, in the collection of products in the sertão (like cacao, barkclove $^{3}$ and sarsaparilla), in colonial defense as troops, and in the cultivation of such crops as manioc, cacao, sugar, and tobacco. Thus, as the Overseas Council explained to the king, in 1645 , "it is impossible to cultivate and fructify the lands of these captaincies without Indians." 4 Two years later, Governor Francisco Coelho de Carvalho stated the necessity of having all the allied Indians prepared for war, since, according to him, on "those Indians depends the defense of this State."

Except for some short periods (1609-1611; 1647-1653; 1680-1688), in seventeenthcentury Portuguese America, Indian enslavement remained legal; it was finally abolished, at least officially, in the mid-eighteenth century. Contrary to that of African slaves, Indian slavery had raised much discussion about its legitimacy among the settlers, missionaries, authorities, the crown, and the Indians themselves, concerning the nature of Indians' freedom and the limits and modes of enslavement. These debates and struggles expressed the views of different groups within the empire and in the colonies, as well as in the Court at Lisbon. ${ }^{6}$ Since the sixteenth century, many royal orders, in accord with papal decrees, sought to define the relationship between Portuguese settlers and the native population. ${ }^{7}$ After the creation of the State of Maranhão, the kings of Portugal

3 Bark-clove, cravo de casca or pau cravo (Dicypellium caryophyllatum), was a bark of a tree which resembled Indian clove in taste, and was widely collected by settlers, becoming one of the main products of Grão-Pará's exports.

4 Arquivo Histórico Ultramarino, Lisbon, Portugal [hereafter AHU], Maranhão, caixa 2, doc. 181, "Consulta from the Overseas Council to Dom João IV," Oct. 24, 1645.

5 Coelho de Carvalho's letter is included in: AHU, Pará, caixa 1, doc. 67, "Requisition from Sebastião Lucena de Azevedo to Dom João IV," [1647].

6 See: Ronaldo Vainfas, Ideologia e escravidão: os letrados e a sociedade escravista no Brasil colonial (Petrópolis: Vozes, 1986); José Eisenberg, As missões jesuíticas e o pensamento político moderno: encontros culturais, aventuras teóricas (Belo Horizonte: Editora da Universidade Federal de Minas Gerais, 2000); Carlos Alberto Ribeiro de Moura Zeron, Linha de fé: a Companhia de Jesus e a escravidão no processo de formação da sociedade colonial (Brasil, séculos XVI $e$ XVII) (São Paulo: Editora da Universidade de São Paulo, 2011).

7 See: José Vicente César, "Situação legal do índio durante o período colonial (1500-1822)," América Indígena vol. 45, no. 2 (1985):391-425. Heloísa Liberalli Belotto, "Política Indigenista no Brasil Colonial, 1570-1750," Revista do Instituto de Estudos Brasileiros, 29 (1988), 49-6o; Beatriz Perrone-Moisés, "Inventário da legislação indigenista. 1500-1800," in História dos índios no Brasil, ed. Manuela Carneiro da Cunha (São Paulo: Companhia das Letras, 1992), 529-566. Francisco Ribeiro da Silva, "A legislação seiscentista portuguesa e os índios do Brasil," in Brasil: colonização e escravidão, ed. Maria Beatriz Nizza da Silva (Rio de Janeiro: Nova Fronteira, 2000), 15-27; Zeron, Linha de fé, 316-369. 
decreed several orders which regulated the use of Indian workers, both free and enslaved, for the operation of Maranhão's economy. As regards Indian labor, changing circumstances in the colony determined the decisions of the crown and the actions of the many groups involved. Therefore, there was a close relationship between colonial reality and the Portuguese Indian policy for the Amazon region.

Certainly Portugal's broader (and previous) colonial experience in South America influenced the decisions taken by the kings, and their enforcement by royal and local authorities in the State of Maranhão. However, one can argue that the specificities of the Portuguese colonization of the Amazon region, and especially the straits faced by the crown to maintain its dominion over this vast territory are essential to understanding the policies related to Indian labor throughout the seventeenth century and the conflicts which derived from them. Undoubtedly, the acquisition and organization of both free and enslaved laborers became one of the main issues among settlers, the crown, royal and local authorities, clerics, and the Indian themselves throughout the colonial period.

Since the mid-nineteenth century, historiography on colonial Brazil defined colonial Indian legislation as contradictory. In the 1850s, João Francisco Lisboa wrote that Portuguese relations with the Indians consisted of an "uninterrupted succession of hesitations and contradictions," until the ministry of the Marquis of Pombal (1751-1777). ${ }^{8}$ The fact that throughout the seventeenth century the crown oscillated between the permission and prohibition of Indian slavery strengthened this perspective, which saw Indian legislation as a battlefield between different groups of colonial society, especially the Jesuits and the settlers, with the crown ceding to each of them alternately. More recently, however, Beatriz Perrone-Moisés reassessed João Francisco Lisboa's analysis, showing that although Indian legislation appeared to be oscillatory, there were some trends that underlay legal determinations. For Perrone-Moisés, who is inspired by a new perspective in Brazilian historiography which stresses the importance and complexity of the role played by the Indians themselves, ${ }^{9}$ Indian policy was also determined by the reaction of the Indian peoples: "acceptance of the system" and "resistance" became basic

8 João Francisco Lisboa, Crônica do Brasil colonial: apontamentos para a história do Maranhão (Petrópolis/Brasília: Vozes/InL, 1976), 406.

9 See: Manuela Carneiro da Cunha, "Introdução a uma história indígena" in História dos índios no Brasil, 9-24; John M. Monteiro, "Armas e armadilhas: história e resistência dos índios," in A Outra Margem do Ocidente, ed. Adauto Novaes (São Paulo: funARTE/Companhia das Letras, 1999), 237-256. 
pillars for the regulation of Portuguese-Indian relations, defining different general policies for "allied" and "hostile" Indians. ${ }^{10}$

This essay argues that one has to understand the so-called "oscillation" of Indian legislation and policy in the Amazon region within a general context of the Portuguese empire from the 1640 s onwards, when Portugal regained its independence from Spain. In fact, the consolidation of the new Bragança dynasty brought increasing intervention of the crown in the region to assure Portuguese control over the territory and to guarantee the incomes of a fragile Treasury. Both imperatives may explain the importance of Indian slavery for the crown in the region.

Thus, from the viewpoint of the crown, the legality of slavery in the northern provinces of Portuguese America lay at an intersection of political struggle (between the different groups in the colony, including the Indians), spatial control over a vast territory, labor problems, and the financing of the Royal Treasury. The second half of the seventeenth century was characterized by an increasing interest from the crown towards the State of Maranhão. In fact, the late 1660 s represented the beginning of a "prolonged depression" which lasted at least until the 169os, "dominated by a crisis in the sugar, tobacco, silver and slave trades."11 Besides many initiatives to face the crisis, the crown implemented the revitalization of some of its colonies' economies, such as that of the State of Maranhão. ${ }^{12}$ It is within this context that one has to understand the significant role played by the crown and the manifold ways by which, beyond Indian labor issues, the Court at Lisbon tried to intervene in the State of Maranhão's economy and society. ${ }^{13}$

\section{Indian Legislation and Indian Slavery}

In seventeenth-century Amazonia, the Indian labor system was defined not only by the legal (and illegal) modes of enslavement, but also by a complex

\footnotetext{
10 Perrone-Moisés, "Índios livres e índios escravos. Os princípios da legislação indigenista colonial (séculos XVI a XVIII)," in História dos índios no Brasil, 115-132.

11 Vitorino Magalhães Godinho, "Portugal and Her Empire, 1680-1720," in The New Cambridge Modern History, ed. John S. Bromley (Cambridge: CUP, 1970), 4: 511.

12 Ibid., 530-531; Carl Hanson, Economia e sociedade no Portugal barroco, 1668-1703 (Lisbon: Dom Quixote, 1986), 247-251; Godinho, "Problèmes d'économie atlantique. Le Portugal, les flottes du sucre et les flottes de l'or (1670-1770)," Annales. Économies, Sociétés, Civilisations vol. 5, no. 2 (1950): 184-197.

13 See: Rafael Chambouleyron, Povoamento, agricultura e ocupação na Amazônia colonial (1640-1706) (Belém, Açaí/U F PA, 2010).
} 
legal apparatus. Portuguese legal definitions of Indians' freedom determined the functioning of the Christian missionary communities (the aldeias, where Indians were indoctrinated), the limits and types of missionaries' temporal jurisdiction over the Indians, the bringing of Indians from the sertão to the aldeias (descimentos), and the distribution of free Indian workers among the settlers, clerics, and the authorities (repartição). None of these issues was exclusive to the state of Maranhão. It was during the second half of the sixteenth and early seventeenth century that many of these problems were faced by the priests and authorities responsible for the conversion of the Indians in Brazil. ${ }^{14}$

Although Indian slavery became an issue of constant discussion, it was never seriously challenged; what became the center of argument was the basis for its legitimization. According to Portuguese laws, there were basically two main sources of legal enslavement: the ransoming of slaves (resgates), and just war (guerrajusta). ${ }^{15}$

The ransoming of slaves consisted of a mechanism to "save" those Indians who had been captured and enslaved by rival tribes, and was practiced by the Portuguese in Africa as well. ${ }^{16}$ It was a Christian task of the Portuguese to "rescue" those Indian slaves from the hands of their enemies - many of whom practiced ritual cannibalism - and bring them to work and ideally to be converted within the Portuguese communities. The troops that ransomed slaves in the sertão (tropas de resgate) were regulated by an ordinance (regimento). However, these troops always had an unclear status, since the Portuguese could enter the hinterland officially for the ransoming of slaves, but eventually declare war on Indian groups, or collect Amazonian spices. ${ }^{17}$ According to an ordinance of 1660 , since two Jesuits were entering the Amazon River in a mission, they were to be escorted by nine soldiers, the leader of whom should only intervene in military issues. Besides these Portuguese soldiers, the bulk of the troop was composed of allied Indians. Although one of the purposes of this

14 Georg Thomas, Politica indigenista dos portugueses no Brasil 1500-1640 (São Paulo: Loyola, 1982); Ronald Raminelli, Imagens da colonização: a representação do índio de Caminha a Vieira (Rio de Janeiro: Jorge Zahar Editor, 1996); Zeron, Linha de fé.

15 See: Ângela Domingues, "Os conceitos de guerra justa e resgate e os ameríndios do norte do Brasil," in Brasil: colonização e escravidão, 45-56.

16 In 1685 , Governor Gomes Freire de Andrade reminded the crown that if resgates were allowed in Africa, there was no reason to ban this practice in Maranhão. "Letter from Gomes Freire de Andrade to Dom Pedro II," AHU, Maranhão, caixa 6, doc. 726, São Luís, Oct, 15,1685 .

17 See: Dauril Alden, "Indian versus Black Slavery in the State of Maranhão during the Seventeenth and the Eighteenth Centuries," Bibliotheca Americana vol. 1, no. 3 (1984): 97; Domingues, "Os conceitos de guerra justa e resgate e os ameríndios do norte do Brasil," 51-52. 
expedition was to preach the Gospel, the regimento specified in detail the distribution of slaves in case of a fortuitous war against Indians, and in case there were Indians who wanted to trade slaves. ${ }^{18}$

War was another important source of legal enslavement on many occasions. The discussion about just war belonged to an old tradition, resumed in Portugal after European settlement in the Americas. ${ }^{19}$ The legitimacy, nature, and regulation of war against the Indians were discussed many times in relation to the State of Maranhão. ${ }^{20}$ Questions about the best times to send military expeditions, the nature of Indian aggression, legal irregularities in the declaration of war, and abuses perpetrated by the Portuguese all had been debated at court, since the sixteenth century.

Over time Indian slavery was allowed and forbidden alternately on many occasions. The list below in Table 2.1 shows the main laws concerning the enslavement of Indians in the State of Maranhão.

\section{Indian Slavery and Labor Policy}

Owing to the importance of Indian labor for the functioning of the Amazonian economy, the Portuguese crown had to constantly intervene in order to regulate the acquisition and use of an Indian labor force. One can argue that there was not a concrete policy concerning the Indians workers throughout the Portuguese conquests in America. Therefore, although the manifold experiences from the several regions of Portuguese territories were certainly linked, there were regional solutions for specific conjunctures. Thus, the captaincies of Bahia and Pernambuco, where an economy based on sugar cultivation prospered, was heavily dependent on African slaves, and had a different place for the Indian worker, both free and slave, than the Amazon region. Even in those regions that relied on Indian workers during the seventeenth century, such as the captaincy of São Paulo (in the southern part of Brazil), there were specific compromises; that was the case of the "private administration" of free Indians by the settlers, actually a veiled slavery,

18 Charles Boxer, "Um regimento inédito sobre o resgate dos ameríndios no Maranhão em 166o," Actas do v Colóquio Internacional de Estudos Luso-brasileiros (Coimbra: Universidade de Coimbra, 1965), 3: 65-71; see also: David Sweet, "A Rich Realm of Nature Destroyed: The Middle Amazon Valley, 1640-1750" (PhD Diss., Univ. of Wisconsin, Madison, 1974), 579-594.

19 See José Sebastião da Silva Dias, Os descobrimentos e a problemática cultural do século XVI (Lisbon: Estampa, 1982), 182-191.

20 See Márcia Mello, Fé e império: as Juntas das Missões nas conquistas portuguesas (Manaus: EdUA, 2009), 304-317. 


\begin{tabular}{|c|c|}
\hline November $10,1647^{21}$ & - abolishes private administration of free Indians \\
\hline $165^{22}$ & $\begin{array}{l}\text { - determines the freedom of all Indians (decree inserted in } \\
\text { the ordinances of the captain-majors of Pará and } \\
\text { Maranhão) }\end{array}$ \\
\hline October $17,1653^{23}$ & $\begin{array}{l}\text { - } \text { revises the } 1652 \text { ordinances } \\
\text { - determines the causes of legal Indian enslavement } \\
\text { - authorizes the ransoming of slaves held by Indian } \\
\text { groups }\end{array}$ \\
\hline April 9, $1655^{24}$ & $\begin{array}{l}\text { - defines the cases of legal enslavement } \\
\text { - determines the examination of the slaves made in } \\
\text { preceding years }\end{array}$ \\
\hline April 14, $1655^{25}$ & $\begin{array}{l}\text { - determines that the Jesuits will have the exclusivity of } \\
\text { free Indians' administration } \\
\text { - determines that Indians' distribution will be made by a } \\
\text { Jesuit and a person elected by the Council } \\
\text { - defines the working period of the Indians and their } \\
\text { payment } \\
\text { - defines the rules for the missionary expeditions to the } \\
\text { sertão }\end{array}$ \\
\hline
\end{tabular}

21 Anais da Biblioteca Nacional [hereafter ABN] vol. 66 (1948): 17-18, "Ley por que S. Mag.de mandou que os Índios do Maranhão sejão livres," Nov. 10, 1647. This law was reinforced in 1649 and 1650. See "P.a o g.or do Maranhaõ," May 29, 1649. AHU, cod. 275, fol. 151; "Para o gov. $^{\text {or }}$ do Maranhaõ," May 14, 1650. AHU, cod. 275, fols. 167-167v.

22 AHU, Maranhão (Avulsos), caixa 3, doc. 321, "Consulta from the Overseas Council to Dom João IV," Sep. 20, 1652. Bernardo Pereira de Berredo, Annaes historicos do Estado do Maranhaõ (Lisbon, na Officina de Francisco Luiz Ameno, 1749), 418, 420.

23 ABN vol. 66 (1948): 19-21, "Provisão sobre a liberdade e captiveiro do gentio do Maranhão," Oct. 17,1653 .

24 ABN vol. 66 (1948): 25-28, "Ley que se passou pelo Secretario de Estado em 9 de abril de 655 sobre os Indios do Maranhão," Apr. 9, 1655. This law was reinforced in 1658 and 1659. See ABN 66 (1948): 29; "Provisão sobre a liberdade do gentio do Maranhão," Apr. 10, 1658. AHU, cod. 92, fols. 321v-322, "Sobre a g.da e observançia da ley doz Indios do Maranhaõ e penna q. se impõem aos q. a naõ obedeçerem," May 16, 1659 .

25 Annaes da Bibliotheca e Archivo Publico do Pará I (1902): 25-46, "Regimento de André Vital de Negreiros, Governador Geral do Estado do Maranhão e Grão-Pará," Apr. 14, 1655. 
- restricts the war against the Indians

- commends the governor to bring Indians from the sertão

September 12, $1663^{26}$

April 1, 168o ${ }^{27}$

December 12, $1686^{28}$ Regimento das Missões

April 28, $1688^{29}$
- abolishes the temporal jurisdiction of the religious orders

- defines that the Councils will elect a responsible official for the distribution of free Indians and a cleric for the ransoming expeditions

- abolishes Indian slavery

- determines that Indians caught in war will be considered only as prisoners

- determines that Jesuits and Franciscans (Province of Santo Antônio) would have the spiritual and "political and temporal" government of the aldeias under their administration

- revokes the April 1, 168o law

- authorizes the ransoming of slaves, which will be undertaken by the Jesuits

- determines that the slaves will be distributed by the Councils

- defines the cases of legitimate slavery by war

26 ABN vol. 66 (1948): 29-31, "Provisão em forma de ley sobre a liberdade dos Indios do Maranhão e forma quem que devem ser admenistrados no espiritual pellos Religiosos da Companhia e os das mais religiões de aquelle Estado," Sep. 12, 1663. This law was detailed in a series of royal orders issued in 1675, 1676, 1677 and 1679: AHU, cod. 268, fols. 9v-10, "P. a o g.or do Estado do Maranhaõ," Apr. 3, 1675. AHU, cod. 268, fols. 13V-14, "Para o governador do Maranhaõ," Sep. 19, 1676. ABN vol. 66 (1948): 44-45, "Provisão em forma de Ley sobre o cabo de escolta das missões do Maranhão e repartição dos índios," Dec. 4, 1677. ABN vol. 66 (1948): 48-49, "Para os officiaes da Camara do Maranhão," Mar. 16, 1679. AHU, cod. 93, fols. 212-212v, "O Bispo do Maranhaõ," Mar. 23, 1679.

27 ABN vol. 66 (1948): 57-59, "Ley sobre a liberdade do gentio do Maranhão," Apr. 1, 1680.

28 "Regimento das missoens do Estado do Maranham \& Parà," Dec. 12, 1686 in Regimento \& leys sobre as missoens do Estado do Maranhã̃, \& Parà, \& sobre a liberdade dos Índios (Lisboa Occidental: na Officina de Antonio Manescal, 1724), 1-16. See: Mello, "O Regimento das Missões: poder e negociação na Amazônia portuguesa," Clio—Série Revista de Pesquisa Histórica vol. 27, no. 1 (2009): 46.

29 ABN vol. 66 (1948): 97-101, "Alvará em forma de ley expedido pelo secretario de Estado que deroga as demais leys que se hão passado sobre os indios do Maranhão," Apr. 28, 1688. 
which consisted of an agreement between the crown and Portuguese settlers, after a series of confrontations between the latter and the Jesuits. ${ }^{30}$

In the Amazon region, labor, especially access to it, was certainly one of the main issues that moved the crown to intervene - not always with success-in the many conflicts derived from the clash of different interests concerning the acquisition and use of Indian laborers, both free and slave. The prohibition of slavery in $165^{2}$ and 1680, and its allowance in 1653 and 1688 were followed by a series of complaints (and sometime violent reactions) by settlers, clerics, authorities, and Indians.

Thus, as Nádia Farage has pointed out, "the dispute and control over Indian labor constitutes the thread that weaves the political history of Maranhão and Grão-Pará." ${ }^{31}$ Historiography has analyzed this key issue for the seventeenth century, examining the complex political relations involved in the dispute over the Indian workers, both free and slave. ${ }^{32}$ These conflicts derived not only from the prohibition of enslavement (in $165^{2}$ and 1680 ), which originated a series of grave complaints, especially from the settlers, which moved the crown to revise these ordinances. They were also linked to the modes of the free Indian administration by the Jesuits (such as stated in 1653, 1655, 1680 and 1686)

30 See Monteiro, Negros da terra: índios e bandeirantes nas origens de São Paulo (São Paulo: Companhia das Letras, 1994); Muriel Nazzari, "Da escravidão à liberdade: a transição de índio administrado pra vassalo independente em São Paulo colonial," in Brasil: colonização e escravidão, Maria B. N. Silva (Rio de Janeiro: Nova Fronteira, 2000), 28-44; Juarez Donizete Ambires, "Os jesuítas e a administração dos índios por particulares em São Paulo, no último quartel do século XVII" (MPhil Thesis, Univ. de São Paulo, São Paulo, 200o); Ambires, "Jacob Roland: um jesuíta flamengo na América Portuguesa," Revista Brasileira de História vol. 25, no. 5o (2005): 201-216; Regina K. Rico Santos de Mendonça, "Escravidão indígena no vale do Paraíba: exploração e conquista dos sertões da capitania de Nossa Senhora de Itanhaém, século XVII" (MPhil Thesis, Univ. de São Paulo, São Paulo, 2009). Nádia Farage, As muralhas dos sertões (São Paulo: Paz e Terra, 1991), 26.

32 For a more recent debate on seventeenth-century Amazonia, see: Almir Diniz de Carvalho Júnior, "Índios cristãos: a conversão dos índios na Amazônia portuguesa (1653-1769)" (PhD Diss., Univ. Estadual de Campinas, Campinas, 2005); Décio de Alencar Guzmán, “A colonização nas Amazônias: guerras, comércio e escravidão nos séculos XVII e XVIII," Revista Estudos Amazônicos vol. 111, no. 2 (2008): 103-139; Camila Loureiro Dias, "Civilidade, cultura e comércio: os princípios fundamentais da política indigenista na Amazônia (1614-1757)" (MPhil Thesis, Univ. de São Paulo, São Paulo, 2009), 49-86; Chambouleyron, Fernanda Aires Bombardi, Vanice Siqueira de Melo, “O 'estrondo das armas': violência, guerra e trabalho indígena na Amazônia colonial," Projeto História, no. 39 (2009): 115-137; Mello, Fé e império, 243-317; Karl-Heinz Arenz, De l'Alzette à l'Amazonie:Jean-Philippe Bettendorffet les jésuites en Amazonie portugaise (1661-1693) (Saarbrücken: Éditions universitaires européennes, 2010); Chambouleyron \& Bombardi, “Descimentos privados de índios na Amazônia colonial (séculos XVII e XVIII)," Varia Historia vol. 27, no. 46 (2011): 601-623. 
and to the control of the Society of Jesus over the legitimization of enslavements made in the sertão $(1653,1655)$. Thus, in 1661 and 1684 , the Jesuits were expelled from the State of Maranhão (the last time, only from the city of São Luís), owing to the conflicts that derived from their control over Indian labor force. ${ }^{33}$

Therefore, there is no doubt that the politics of the State of Maranhão influenced labor policy, and the fragile equilibrium the crown had to maintain between different groups within colonial society, including the Indians themselves. However, one can also argue that Indian slavery was also linked to the ways the crown envisaged the reproduction of its own power over the vast territory of the State of Maranhão.

During the seventeenth century, in many captaincies of the State of Brazil, such as Pernambuco, war became an important mechanism for the imposition of Portuguese dominion over the Indians and territory; thus the Portuguese undertook military expeditions against the Indians for the "cleansing of the sertões"; ${ }^{34}$ in the State of Maranhão however, it was also an important means of acquiring Indian slave labor. ${ }^{35}$

An example of this double dimension of war was the one fought against the Amanaju in 1689. According to Governor Artur de Sá e Meneses, following the royal decision taken on April 28, 1688, a Junta voted for the legality of the war against that native nation. The expedition was commanded by Captain-Major Antônio de Albuquerque Coelho de Carvalho (later governor of the State), and

33 For a recent discussion on these two revolts, see: Geraldo Mártires Coelho, "A pátria do Anticristo: A expulsão dos jesuítas do Maranhão e Grão-Pará e o messianismo milenarista do Padre Vieira," Luso-Brazilian Review, vol. 37, no. 1 (200o): 17-32; Milson Coutinho, $A$ revolta de Bequimão, 2nd ed. (São Luís: Instituto Geia, 2004); Chambouleyron, “'Duplicados clamores'. Queixas e rebeliões na Amazônia colonial (século XVII)," Projeto História no. 33 (2006): 159-178; Joely Pinheiro Ungaretti, "Conflitos entre jesuítas e colonos na América portuguesa (1640-1700)" (MPhil Thesis, Univ. Estadual de Campinas, Campinas, 2007), 109-178; Antônio Filipe Pereira Caetano, Entre drogas e cachaça: A política colonial e as tensões na América portuguesa (1640-1710) (Macieó: EdUFAL, 2009); Arenz, De l'Alzette à l'Amazonie, 103-106 and 371-388.

34 See for example, Ricardo Pinto de Medeiros, "O descobrimento dos outros: povos indígenas do sertão nordestino no período colonial” (PhD Diss. Univ. Federal de Pernambuco, Recife, 200o), 114-149; Pedro Puntoni, A guerra dos bárbaros. Povos indígenas e a colonização do sertão nordeste do Brasil, 1650-1720 (São Paulo: Hucitec/EdUSP, 2002); Friedrich Câmera Siering, "Conquista e dominação dos povos indígenas: resistência no sertão dos Maracás (1650-1701)” (MPhil Thesis, Univ. Federal da Bahia, Salvador, 2008), 51-83.

35 Moreover, Vanice Siqueira de Melo showed, for the early eighteenth-century State of Maranhão, that war was an important source of power, especially for the governors, since part of the booty had to be given to the governor as an official tax (called jóia). Melo, "Cruentas guerras: índios e portugueses nos sertões do Maranhão e Piauí (primeira metade do século XVIII)," (MPhil Thesis, Univ. Federal do Pará, Belém, 2011), 112-125. 
comprised Portuguese troops as well as Indians of allied peoples, such as the Tupinambá, the Aruaqui and the natives of the aldeia Maracanã (in the captaincy of Pará). The governor explained that the allied Indians attacked with such a fury that "the corporals and soldiers were not enough" to prevent the killings. As a result, and unfortunately for the Portuguese, almost no prisoners were taken. ${ }^{36}$ However, it seems there was more at issue than slaves in the Amanaju war. Investigating the reasons of this conflict, Vanice Siqueira de Melo found evidence that the initial "aggression" of the Amanaju (which legitimized the military expedition) was motivated by the presence of Portuguese and allied Indians exploiting bark-clove in the Indians' territory (in the Cabo do Norte). ${ }^{37}$ War thus could mean both a means to acquire Indian slaves, and also to gain control over a territory of economic interest.

Some years earlier, this was the same reason used by the Portuguese to declare war against the Taconhapé, in the Xingu River. This war, though, was fought before the 1688 law, and prisoners could not be officially enslaved. Similarly to legitimations of the Amanaju war, the Portuguese justified this conflict owing to the killing of some white people by the Indians; Portuguese settlers were frightened to enter this sertão, where they used to gather spices. That was the reason alleged by the Belém Council to the governor. The royal resolution authorizing the war stressed that the punishment should be "exemplary" but should not lead to the "total destruction" of the Taconhapé. ${ }^{38}$ As stated by the Jesuit father João Felipe Bettendorff, the Taconhapé territory had "amounts of bark-clove," and even the difficulties encountered by the settlers navigating on the Xingu's dangerous currents were not enough to deter the exploiters of clove, the "cravistas," who "risk all to gather clove wherever it is." 39 Thus victory over the Taconhapé permitted the "opening" of the Xingu sertão to the exploitation of Amazonian spices. ${ }^{40}$

The conflict with the Caicai and Guanare on the eastern frontier of the State of Maranhão, in the early 1690 s is paradigmatic of how war represented an

36 AHU, Pará, caixa 3, doc. 278, “Letter from Artur de Sá e Meneses to Dom Pedro II," Belém, Nov. 29, 1689. .

37 Melo, “'Aleivosias, mortes e roubos'. Guerras entre índios e portugueses na Amazônia colonial (1680-1706)” (вA Thes., Univ. Federal do Pará, Belém, 2008), 50.

38 AHU, Maranhão, caixa 6, doc. 662, "Consulta from the Overseas Council to Dom Pedro II," Mar. 10, 1682.

39 João Felipe Bettendorff, sJ, Crônica da missão dos Padres da Companhia de Jesus no Maranhão (Belém: SECULT, 1990[1698]), 279.

40 See: Chambouleyron, "O sertão dos Taconhapé. Cravo, índios e guerras no Xingu seiscentista," in Histórias do Xingu: fronteiras, espaços e territorialidades (XVII-XXI), ed. César Martins Sousa \& Cardoso (Belém: EdUFPA, 2008), 51-74. 
intersection between territorial struggles and labor supply. ${ }^{41}$ These people used to ravage the settlers' estates, killing slaves and setting fires on their properties. It was a necessity, thus, to "disinfest" the sertões of the rivers Itapecuru, Mearim and Munim. The declaration of this war followed all the legal procedures established by the law issued on April 28, 1688. A Junta approved the "justice" of the war and two judicial inquiries were established by a judge, with the testimony of sixteen and ten witnesses (respectively). Prisoners were enslaved and some of them distributed among the troops. The Overseas Council considered it legal. As usual, the sovereign requested the opinion of former Governor Freire de Andrade. In his paper, Freire de Andrade considered the reasons for war as justified. However, he also wrote a revealing remark:

It should be recommended to the governor, that in this issue he follow strictly His Majesty's law, restricting as much as possible the execution of such punishment, because settlers' designs on the Indians render their witness untrustworthy to determine the guilt of the natives. ${ }^{42}$

Gomes Freire's warning could not have been more opportune. Four years later, a second war was organized by Governor Antônio de Albuquerque Coelho de Carvalho against the Caicai. However, 800 of these Indians went beforehand to the Itapecuru fortress asking for peace. According to the governor, the captainmajor and the settlers of Itapecuru decided nevertheless to capture the Indians, many of whom resisted only to be seized by the Portuguese. Coelho de Carvalho decided then to annul the enslavements. ${ }^{43}$ His decision was approved by the Overseas Council and the king. ${ }^{4}$

Although the crown did not consider this last war legitimate, there is no doubt that there was a delicate equilibrium between war and slavery for its

41 Mauro da Costa Oliveira argues that what historiography has considered as a territorial expansion in the Portuguese Amazon region motivated by geopolitical objectives was in fact the result of enslavement which spread Portuguese dominion all over this vast territory. Although this is an interesting viewpoint, one cannot dismiss the role frontier issues played for the Portuguese crown in the region. Mauro da Costa de Oliveira, "Escravidão indígena na Amazônia colonial” (MPhil Thesis, Univ. Federal de Goiás, Goiânia, 2001). AHU, Maranhão, caixa 8, doc. 862, "Consulta from the Overseas Council to Dom Pedro II," Feb. 10, 1693 .

43 AHU, "Maranhão, caixa 9, doc. 912, Consulta from the Overseas Council to Dom Pedro II," Jan. 26, 1696.

44 ABN vol. 66 (1948): 159, "Sobre se dar livramento aos culpados que concorrerão no captiveiro do gentio," Feb. 1, 1696. 
own interests. The fact that the conflicts took place in the margins of the State of Maranhão shows that the kings took advantage of the struggles to impose royal authority in the frontiers of the Amazon region; not surprisingly, in the late seventeenth and early eighteenth century, a third war was fought against the "corsair Indians" of the rivers Itapecuru and Mearim, where the Portuguese were gradually establishing an economy based mainly in sugar cane cultivation and cattle breeding. ${ }^{45}$

\section{Slavery, Royal Power and the Treasury}

Defined in 1653, 1655 and 1688 , the resgates were an important means of acquiring Indian slaves for the settlers, and even for the crown, thus becoming a central part of the Portuguese Indian policy in the Amazon region. In fact, the regulation of the resgates, and that of Indian slavery in general, was closely linked to the financing of the royal Treasury throughout the colonial period; as Camila Dias points out, towards the end of the seventeenth century, the resgates "served a political-economic project of the Portuguese State itself." 6 Being a frontier region, and certainly not a wealthy conquest, the State of Maranhão's royal Treasury faced serious straits, especially for the financing of the fortresses and troops. Thus, the taxation of Indian slaves became a coveted source of income for the crown.

From the late 1650 s onward, both in Maranhão and at Court, the royal authorities presented plans for the collection of taxes from slaves. In 1659, King Afonso VI determined the governor of Maranhão to inform his opinion regarding a tax over the slaves, for the financing of the journeys to the sertão. ${ }^{47}$ Governor Dom Pedro de Melo replied stating that instead of a tax, which would not be accepted by the people, the sovereign should order a percentage of slaves (one out of ten) to be given to the Treasury (as it was usually done with the corporals, soldiers, and Indians who went on the ransoming expeditions) ${ }^{48}$

45 See Maria do Socorro Coelho Cabral, Caminhos do gado: conquista e ocupação do sul do Maranhão (São Luís, Sioge, 1992); Ana Paula Macedo Cunha, "Engenhos e engenhocas: a atividade açucareira no Estado do Maranhão e Grão-Pará (1706-1750)" (MPhil Thesis, Univ. Federal do Pará, Belém, 2009); Chambouleyron, Povoamento, ocupação e agricultura na Amazônia colonial, 121-151.

46 Dias, "Civilidade, cultura e comércio," 128.

47 AHU, cod. 275, fol. 306, "Para o g. ${ }^{\text {or }}$ do Maranhaõ," May 6, 1659.

48 AHU, Maranhão, caixa 4, doc. 421, "Letter from Dom Pedro de Melo to Dom Afonso VI," São Luís, Feb. 7, 1660. 
A few years later, an anonymous author wrote some considerations for the "common welfare" of Maranhão, and suggested that the settlers should pay two to four rods of cotton cloth (which circulated as currency in the State of Maranhão), for each ransomed slave. ${ }^{49}$

It was only in the 1670 , though, that the crown took this taxation seriously and determined the payments of tithes regarding the slaves brought from the hinterland. Not surprisingly, the regency $(1667-1683)$ and especially the reign (1683-1706) of Dom Pedro II was defined by Nuno Monteiro as characterized by the consolidation of the Bragança dynasty and by the "restoration of a well defined model of political decision-making." ${ }^{50}$ Thus, in April 3, 1675, the prince decided to impose the payment of this tax. ${ }^{51}$

After the 1688 law, which reinstated the resgates, the role played by slavery for the financing of the royal Treasury became not only evident, but systematically organized, increasing and making more efficient "the control over the payment of taxes on ransomed slaves," as Márcia Mello stresses. ${ }^{52}$ First of all, the crown determined that the ransoming troops would be financed by the Treasury, which would allocate three thousands cruzados (1,440,00o réis) for the purchase of slaves in the sertão. Moreover, for each slave taken the settlers would pay 3,00o réis to finance more journeys to the hinterland. A special registry would be kept for all these payments.

In July 1689, for example, the Council of São Luís, captaincy of Maranhão, registered 124,416 réis received by the royal Treasury related to twenty-six people brought from the sertão by Francisco Ferreira Bernardes, "for the work in the cane fields" (not all the slaves paid 3,00o réis). In October of the same year, the settlers of São Luís paid 137,791 réis, related to thirty-two slaves ransomed by an expedition undertaken by Sergeant-Major Lemos de Mascarenhas. ${ }^{53}$ In

49 AHU Maranhão, caixa 4, doc. 465, "Paper Concerning the State of Maranhão," Feb. 24, 1663.

50 Nuno Gonçalo Monteiro, "A consolidação da dinastia de Bragança e o apogeu do Portugal barroco: centros de poder e trajetórias sociais (1668-1750)," in História de Portugal, ed. José Tengarrinha (Bauru/São Paulo/Lisboa: EdUSC/EdUNESP/Instituto Camões, 2000), 130. AHU, cod. 268, fols. 9v-10, "P. o o g.or do Estado do Maranhaõ," Apr. 3, 1675.

52 Mello, Fé e império, 276.

53 Unfortunately, data related to the incomes of the royal Treasury are extremely fragmented and inaccurate for the seventeenth and first half of the eighteenth centuries. There is a number for 1688, when the captaincy of Maranhão tithes represented almost 1.7 million réis. Taking this number as correct and as a reference for 1689, the taxes paid by slave buyers in the two expeditions represented $15 \%$ of this amount. AHU, Maranhão, caixa 7 , doc. 821, "Consulta from the Overseas Council to Dom Pedro II," Sep. 18, 169o. One has to remember that 1689 was the first year when this tax was systematically exacted by the Treasury. 
April 1691, thirty-two more slaves were distributed among the dwellers of this city, paying 157,650 réis. ${ }^{54}$

Tamyris Monteiro Neves points out that these measures have to be understood as an important means for the crown to generate resources for the Treasury, which she shows were used in a series of different activities: the financing of the ransoming troops, including pecuniary support for the descimentos of free Indians, the payment of services rendered by settlers to the crown, the construction and renovation of buildings, the financing of the fortresses and military troops, and the payment of judiciary costs for the Indians themselves. ${ }^{55}$

Towards the end of the century, however, more changes were introduced, and a new institution became central for the organization of a labor policy and as a mechanism for the crown to try to control enslavement in the Amazon region.

\section{Royal Control and the Junta das Missões}

Throughout the seventeenth century, the many regulations concerning the modes and limits of enslavement did not mean that the Portuguese refrained from illegally enslaving Indians, or that, when it was allowed, they followed all the legal procedures for the dispatch of an expedition and for ensuring the legitimacy of each slave taken by war or ransoming. As Sue Gross asserts for the first half of the eighteenth century, but perfectly applicable to the seventeenth century, illegal enslaving was "widespread and almost impossible to control."56

In 1650, for example, Governor Luís de Magalhães accused the captainmajor of Pará of ransoming 150 slaves. ${ }^{57}$ In turn, Luís de Magalhães himself was later charged with having sent troops to the sertão to ransom slaves, under the pretense that they had been sent to discover gold. ${ }^{58}$ Years later, in 1667 , the

54 Arquivo Público do Estado do Maranhão, São Luís, Brazil, fols. 2-5; 5V-9v and 11-15v, respectively, "Livro de Registro Geral (1689-1746)."

55 Tamyris Monteiro Neves, "Entre salvar almas para Deus e gerar lucro para a Fazenda real: a empresa dos resgates" (BA Thes., Univ. Federal do Pará, Belém, 2011), 42-46.

$5^{6}$ Sue Anderson Gross, "Labor in Amazonia in the First Half of the Eighteenth Century," The Americas vol. 32, no. 2 (1975): 216. See also: Sweet, "A Rich Realm of Nature Destroyed," 479-480; Farage, As muralhas dos sertões, 28-31; Dias, "Civilidade, cultura e comércio," 90; Mello, Fé e império, $283^{-287}$.

57 AHU, Maranhão, caixa 3, doc. 284, "Letter from Luís de Magalhães to Dom João IV," São Luís, Jan. 28, 165 o.

$5^{8}$ AHU, Maranhão, caixa 3, doc. 300, "List of accusations against Luís de Magalhães" [165os]. 
representative of Pará at court, Vicente de Oliveira, accused Governor Rui Vaz de Siqueira of sending troops to the sertão for resgates, against the regulations of the September 12, 1663 law. $^{59}$

Some years later, before the abolition of slavery in 1680 , the royal treasurer reported the confiscation of thirty-seven slaves, ransomed contrary to the regulations. ${ }^{60}$ In fact, the practice was so widespread that when Governor Artur de Sá e Meneses ordered a judge to investigate who had sent troops for the resgates during a period when they were banned from 1680 until 1688, he discovered that almost all of Pará's settlers were involved. Both decided not to continue the inquiry, since it would "destroy this land," and, instead asked the king for a general pardon. ${ }^{61}$ Analyzing this case, the Overseas Council agreed with the opinion of the royal counselor, for whom there existed many examples in human history, where "the abundance of criminals rendered impossible punishment and facilitated remission." ${ }^{22}$ On February 6, 1691, the king pardoned all the settlers, "to avoid the total ruin which that people would experience."63

The recurrence of illegal enslavement, although pardoned by the king in 1691, led to an intensified (although not always efficient) control from the crown and the royal authorities in the State of Maranhão. On the one hand, the king tried to increase the control over the canoes sent to the sertão, which were the unique means of bringing Indians from the hinterland. ${ }^{64}$ On the other hand, he recommended the enforcement of the ransoming law of 1688 , and tightened the punishments for those who committed infractions.

Moreover, the installation of the Junta das Missões - Missions Junta—in the early 1680 s meant the establishment of an organism responsible for the control and regulation of missionary and Indian matters, although it began to work effectively only after the approval of the Regimento das Missões (1686). ${ }^{65}$

59 AHU, "Pará, caixa 2, doc. 132, "Consulta from the Overseas Council to Dom Afonso vi," Jan. 26,1667 .

6 AHU, cod. 274, fols. 13v-14, "Sobre o que escreve o Provedor da Faz. a do Estado do Maranhaõ," Jun. 26, 1679 .

61 AHU, Pará, caixa 3, doc. 276, "Letter from Artur de Sá e Meneses to Dom Pedro II," Belém, Nov. 27,1689 .

62 AHU, cod. 274, fols. 69v-70, "O governador do Estado do Maranhaõ Artur de Saa e Meneses dà conta em como os mais dos moradores daquelle Estado haviaõ feito resgates de escravos contra as ordens de S.Mg. de, Oct. 7, 1690.

63 AHU, cod. 94, fols. 131v-132, "Sobre serem perdoados os moradores do Maranhaõ que tiverem encorrido no crime de fazer escravos contra a ley de S. Mag. de," Feb. 9, 1691.

64 AHU, cod. 94, fols. 157-157V, "Sobre o registro das canoas," Feb. 6, 1691.

65 Mello, Fé e império, 159-163. 
Composed by the governor, the bishop, and the prelates of the different religious orders acting in the region, besides missionary issues, the Junta became more and more concerned with the definition of what Márcia Mello calls "the development of an Indigenous policy by the Portuguese state." Thus, the Juntas in the captaincies of Maranhão and Pará analyzed questions such as the bringing of free Indians from the hinterland, the legitimacy of ransoming enslavements, declaration of wars, and so forth. ${ }^{66} \mathrm{~A}$ royal letter issued on November 20, 1699 defined this more influential role played by the Mission Junta, since it determined that any expedition to the hinterland had to be authorized by the Junta das Missões. ${ }^{67}$ Márcia Mello correctly indicates that the Juntas cannot be understood simply from their regulatory function as regards the missions and missionaries. They acted both as a mechanism of political control and as an official forum where different groups in this society sought solutions for the recurring problem of labor supply. ${ }^{68}$

Labor supply and labor regulations constituted a serious problem for the state of Maranhão. The contradictory nature of labor legislation, political pressure from different groups of colonial society, specific conjunctures such as epidemics and Indian resistance, all transformed labor into a key issue in the colonial Amazon region. Uncertainty about labor supply seriously hindered economic production, as the many complaints sent from the "conquest" expressed so clearly.

Nevertheless, throughout the seventeenth century, the economic development of the state of Maranhão, related to the exploitation of the forest products and the increase of agricultural activity, which concerned the settlers and the crown (particularly troubled by the reproduction of the military and royal institutions in the region) could not be promoted without addressing labor questions. Legislation and royal orders should not be seen as the main basis for

66 Mello, Fé e império, 176-178. See also:Wojtalewicz, "The Junta de Missões/Junta de Misiones: A Comparative Study of Peripheries and Imperial Administration in Eighteenth-Century Iberian Empires," Colonial Latin American Review vol. 8, no. 2 (1999): 225-240; Souza Jr., "Tramas do cotidiano," 209-216.

67 ABN vol. 66 (1948): 192, "Sobre se permitirem os resgates a requerimento dos officiaes da Camara do Maranhão," Nov. 20, 1699.

Mello, Fé e império, 178. 
social change in the state of Maranhão. ${ }^{69}$ Nonetheless, the role the crown itself tried to play in this frontier region-spurring its economic development and territorial occupation as well as addressing the interests of the many groups that constituted colonial society-shaped the way the Amazonian society was organized and had a profound influence on the lives of the many Indian nations who inhabited this northern province of Portuguese America.

Contrary to other parts of its vast empire, the Portuguese crown intervened in many aspects of Amazonian economy and society, where Indian labor had become an essential element of colonial dominion, since control over the Indians also meant control over the frontiers and over the reproduction of its own power in the region. That was the reason why, throughout the seventeenth century, the kings of Portugal and their councils at Court had to negotiate, sometimes reviewing former decisions, with the many demands from the settlers, colonial authorities, local elites, clerics and the Indians.

69 As David Sweet indicates, historiography overemphasized "changes in law" as "milestones in the course of social change." Sweet, "A Rich Realm of Nature Destroyed," 145. 